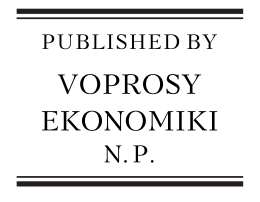

\title{
Testing and interpreting uncovered interest parity in Russia
}

\author{
Dmitry Vasilyev $^{\mathrm{a}, *}$, Vladimir Busygin ${ }^{\mathrm{a}}$, Sergey Busygin ${ }^{\mathrm{b}}$ \\ ${ }^{a}$ National Research University Higher School of Economics, Moscow, Russia \\ ${ }^{b}$ Novosibirsk State University, Novosibirsk, Russia
}

\begin{abstract}
The failure of uncovered interest rate parity (UIP) is a well-known phenomenon of the last thirty years. UIP failure is more prominent in advanced economies than in emerging market economies. Typically, UIP estimation for an advanced economy generates a negative coefficient, meaning that a higher interest rate in advanced economy A will result in the appreciation of economy A's exchange rate. For emerging market economies, higher interest rates usually correspond to future depreciation, although this depreciation is not sufficient for UIP to hold. This paper shows that UIP holds in Russia better than in other emerging market economies when the UIP equation accounts for a constant risk premium. Consequently, there is no forward premium puzzle for Russian data for 2001-2014. To determine the results for Russia and to compare them with the results for other countries, we estimate UIP first for Russia and then for advanced and emerging market economies using seemingly unrelated regressions and panel data analysis. By comparing the profitability of static and dynamic carry trade strategies, we also confirm that in emerging market economies, risk premiums are often constant, whereas in advanced economies, risk premiums are almost always volatile. This may explain why UIP holds better in emerging market economies. It also enables us to formulate a hypothesis that macroeconomic policies of emerging market economies (e.g., the accumulation of large foreign exchange reserves) stabilize risk premiums.

C 2017 Non-profit partnership "Voprosy Ekonomiki”. Hosting by Elsevier B.V. All rights reserved.
\end{abstract}

JEL classification: F31, F32, G15.

Keywords: interest parity, forward premium puzzle, carry trade, risk premium, foreign exchange reserves.

\footnotetext{
The updated English version of the article published in Russian in Ekonomicheskaya Politika, 2016, Vol. 11, No. 4, pp. 35-55.

* Corresponding author, E-mail address: for.vasiliev@gmail.com

Peer review under responsibility of Voprosy Ekonomiki.
} 


\section{Introduction}

\subsection{What is the uncovered parity puzzle and how is it related to carry trade and to the forward premium puzzle?}

Uncovered interest parity (UIP) has been widely used as an exchange rate prediction tool over the past forty years. Dynamic stochastic general equilibrium (DSGE) models used by central banks also use the uncovered parity of interest rates to simulate exchange rates. UIP failure challenged such models and motivated economists to make ad-hoc amendments to account for deviations from UIP (Adolfson et al., 2007; Kollmann, 2004; Wang, 2010).

UIP is no-arbitrage condition in equilibrium:

$$
\frac{1+i}{1+i^{s}}=\frac{E_{t}\left(S_{t+k}\right)}{S_{t}},
$$

where $i$ is the nominal interest rate and where $\mathrm{s}$ is the inverse exchange rate (the value of USD in RUB in our example).

When UIP holds, a higher risk-free interest rate, e.g., in Russia compared to the U.S., denotes expectations for Russian ruble depreciation. A persistent failure of UIP means that investments made in a currency with higher interest rates will earn stable profits due to the interest rate spread between the two countries and due to an increase or insufficient decline in the rate of that currency. The failure of UIP is reflected by the use of carry trade strategies and by the forward premium puzzle.

A forward premium puzzle occurs when UIP is tested using a time series. Bilson (1981), and Hansen and Hodrick (1980) use a time series analysis to show UIP failure. The $\beta$ factor is negative in the regressions: a higher interest rate is followed by appreciation.

At the same time, several studies have demonstrated that the forward premium puzzle can be shown to be non-existent in some cases. For example, the forward premium puzzle is not confirmed over long time periods of five to ten years (Chinn and Meredith, 2004; Chinn, 2006; Chinn and Quayyum, 2012). The forward premium puzzle is much less common in emerging market economies (EMEs) than in advanced economies (AEs) (Bansal and Dahlquist, 2000; Frankel and Poonawala, 2010).

The carry trade approach is an investment strategy through which an investor borrows in a currency with a low interest rate while at the same time making investments in a currency with a high interest rate. High and sustainable returns ensured by the carry trade strategy have been demonstrated, for example, in Burnside et al. (2012), and Menkhoff et al. (2012). Galati et al. (2007) presents a measure for the volume of carry trade transactions. The profitability of such currency strategies appears to spur highly volatile international capital flows (Burnside et al., 2012).

A number of works on exchange rate trends have attempted to explain why interest parity may be not realized while carry trade may earn income. Engel (2015) presents a survey of literature dedicated to possible explanations for why the $\lambda$ of equation (2) can deviate from zero.

$$
\lambda_{t}=i_{t}-E_{t} s_{t+1}+s_{t}-i_{t}^{*}
$$


where $\lambda$ is the deviation from interest parity, $i^{*}$ is the foreign interest rate, $i$ is the domestic interest rate $s$ is the exchange rate logarithm, and $E_{t} s_{t+1}$ is the next period expected exchange rate logarithm.

First, market agents may require higher returns from a foreign asset when there is a premium for the exchange rate risk (Backus et al., 2001; Brandt et al., 2006). Second, expectations can be irrational. Third, the peculiarities of the foreign exchange market and of its microstructure and capital controls can affect the realization of interest parity (see an overview in Evans, 2011).

\subsection{Earlier UIP estimates for Russia}

For Russia, the hypothesis on deviations from uncovered interest parity, given different exchange rate regimes, is tested in Gurvich et al. (2009) based on a time series for 2001 to 2008. In other words, the authors verify the existence of the forward premium puzzle. According to their findings, the deviations from UIP occured in 2005 as a result of the transition from dollar targeting to dual-currency basket targeting and due to higher levels of uncertainty that resulted with respect to the future foreign exchange rate. To explain what they discovered, the authors hypothesized that the exchange rate trend is easier to predict for EMEs. Frankel and Poonawala (2010) attribute the comparatively better precision of exchange rate estimates in such economies to high inflation and accordingly to the stable exchange rate trend.

At the same time, this raises questions regarding how this hypothesis corresponds to those revealed in Clarida et al. (2009) and Menkhoff et al. (2012): the profitability of the carry trade strategy increases (UIP is increasingly farther from realization) as exchange rate volatility decreases (higher volatility points to a greater degree of error in estimates of the future exchange rate).

If hypotheses formulated in Frankel and Poonawala (2010), Clarida et al. (2009), and Menkhoff et al. (2012) are correct, then UIP never holds. If the exchange rate is highly volatile, no carry trade occurs. However, the forward premium puzzle remains. When exchange rate volatility is low, the forward premium puzzle does not exist, but carry trade does (Table 1). At the same time, the results presented in this article indicate that UIP holds in several EMEs.

With a longer time series at our disposal, we attempted to test UIP in Russia between 2001 and 2014. We found that the forward premium puzzle is not verified by Russian data for the period reviewed, including both a period of constantly increasing real exchange rates and a period of higher uncertainty with respect to the exchange rate trend, whereas the $\beta$ factor is close to one. At the same time, the free constant $\alpha$ in the equation for evaluating UIP over the time series does

Table 1

Exchange rate volatility and UIP realization*.

\begin{tabular}{lll}
\hline & High exchange rate volatility & Low exchange rate volatility \\
\hline Forward premium puzzle & + & - \\
Carry trade is profitable & - & + \\
UIP is realized & - & - \\
\hline
\end{tabular}

* According to the hypothesis formulated in Frankel and Poonawala (2010) and to the findings of Clarida et al. (2009), and Menkhoff et al. (2012). 
not equal zero. The significance of the constant term corresponds to the evaluation of the carry trade strategy for Russia. The profitability of carry trade is related to the constant risk premium. ${ }^{1}$ The constant risk premium is expressed as a significant constant in the forward premium puzzle evaluation.

The following text is divided into three sections. The first part verifies that UIP is realized when using Russian data, and it formulates a hypothesis that explains why UIP is realized in Russia but not in the majority of other countries. The second part verifies the existence of a forward premium puzzle in EMEs and AEs and evaluates the role of risk premium volatility in returns on carry trade investments in such countries. The concluding section presents our main findings.

\section{Verification of UIP realization using Russian data}

\subsection{Realization of covered interest parity (CIP)}

The simplest proof that CIP holds is that the forward market exists. If covered interest parity were not realized, this would imply that the stable arbitrage serves as an obstacle to market existence (Frankel and Poonawala, 2010).

There are also two standard approaches to check that CIP holds: econometric and descriptive approaches (an analysis of gaps between the actual interest rate and "implied" interest rate based on the forward exchange rate). Using the econometric approach, Gurvich et al. (2010) found that covered parity has been realized in Russia based on data for September 2001 to July 2008. Our paper presents a descriptive analysis of data for August 2005 to May 2014.

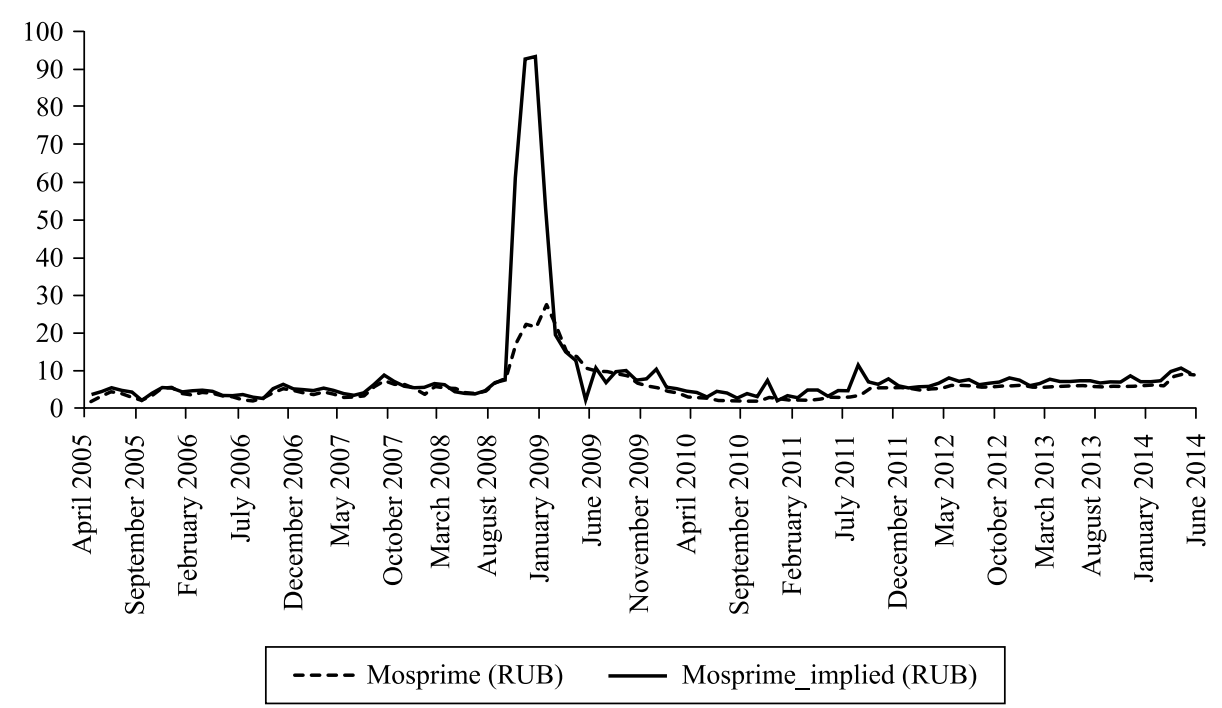

Fig. 1. Covered interest parity (\%).

Sources: Bloomberg; authors' calculations.

\footnotetext{
${ }^{1}$ Like Hassan and Mano (2014), and Burnside (2015), we define risk premiums as returns on the carry trade foreign exchange portfolio.
} 
Fig. 1 features a graph of implied and actual interest rates. The Mosprime rate, calculated from May 2005, is used as the actual rate. The implied rate is calculated on the basis of the forward exchange rate:

$$
i_{\text {impl }}=f_{t}-s_{t}+i^{*},
$$

where $f_{t}$ is the forward rate; $s_{t}$ is the spot rate; and $i^{*}$ is the foreign interest rate (LIBOR in USD).

During the crisis, covered parity did not hold for a great number of currencies as a result of the sharp rise in the counterparty risk premium (this premium is usually considered to be effectively zero for short-term inter-bank loans; see Baba and Packer, 2009). As a result of sudden and dramatic capital flight during the 2008-2009 crisis, covered parity for the Russian ruble was not realized between October 2008 and January 2009.

We can see that CIP held 2001 to 2014, except for the crisis period. The volatility of mosprime_implied around the mosprime series (see Fig. 1) may be attributed to the quality of data obtained by aggregating information across various counterparties.

\subsection{Deviations from UIP: carry trade and the forward premium puzzle}

\subsubsection{Carry trade}

Average carry trade returns on the ruble exceeded 4\% from 2001 to 2014 (except during the 2008-2009 crisis). Dynamic carry trade (equation 4) yielded $4.61 \%$ on average, and static carry trade (equation 5) yielded $5.63 \%$. We use the same method to evaluate the role of risk premium volatility as that used in Burnside (2015). Dynamic carry trade occurs when an investor takes a long position in a currency if it demonstrates a positive forward premium at the present moment. Static carry trade denotes that a long position in a currency is taken when the average forward premium exceeds zero over the entire period considered. The difference between forward and future rates is equivalent to $\lambda$ from equation (2). The excess in returns from the static carry trade over dynamic carry trade suggests that a constant risk premium explains the profitability of carry trade in Russia.

$$
\begin{aligned}
& x^{d y n}=\operatorname{sign}\left(f_{t}-s_{t}\right) \cdot\left(f_{t}-s_{t+1}\right) ; \\
& x^{\text {stat }}=\operatorname{sign}\left[E\left(f_{t}-s_{t}\right)\right] \cdot\left(f_{t}-s_{t+1}\right),
\end{aligned}
$$

where $x^{d y n}$ is the returns on dynamic carry trade, $x^{\text {stat }}$ is the returns on static carry trade, and $\operatorname{sign}(. .$.$) returns the sign of the expression in parentheses.$

Fig. 2 shows that the average forward premium of the Russian ruble was positive from 2001 to 2004 and after 2008. Negative values of the forward premium for 2005 to 2007 coincide with a period of strong private capital inflow into Russia. This result may depend on data that we use, as the analysis focuses on the difference between risk-free rates on loans maturing in 1 month. A negative forward premium for the ruble was observed during the mid-2000s, when the US 


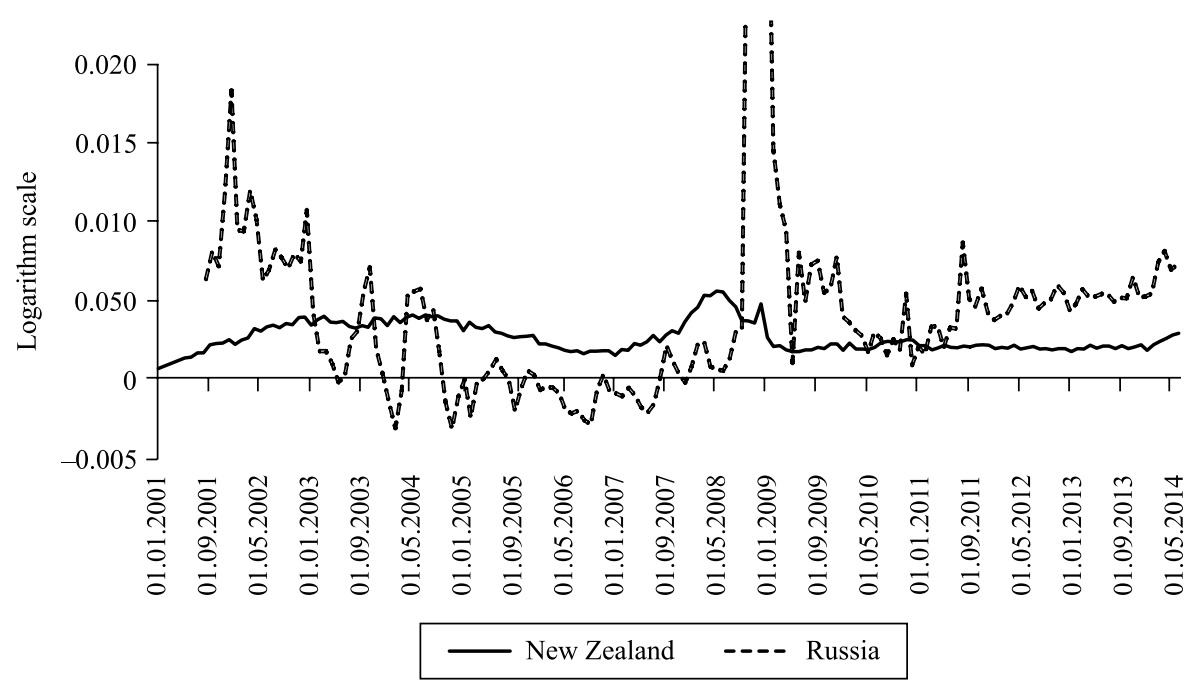

Fig. 2. Forward premium.

Sources: Bloomberg; authors' calculations.

Federal Reserve could not raise long-term interest rates and instead raised shortterm rates. Consequently, short-term risk-free ruble rates were lower than the corresponding USD rates. If we look at rates on 10-year government bonds, we can easily see that ruble rates exceeded USD rates during this period.

There are reasons to believe that a constant risk premium underlies returns on carry trade transactions for the ruble. If the forward premium puzzle is explained by the volatility of risk premiums, then we should see no forward premium puzzle in Russia's case.

\subsubsection{Forward premium puzzle}

No forward premium puzzle is observed from monthly Russian data for the period of 2001 to 2014 . The $\beta$ factor in equation (6) is positive and approaches 1 :

$$
s_{i, t+1}=\alpha+\beta\left(f_{i, t}-s_{i, t}\right)+\varepsilon_{i, t+1},
$$

where $\alpha$ is a constant, $\beta$ is the estimated coefficient, and $\varepsilon$ is the error.

Below are the estimates of the $\beta$ factor based on the simple least squares method and on weighted least squares for the entire sample and for the sample excluding months of the 2008-2009 crisis (Table 2). It should be stressed that in all specifications of equation (6) for the Russian ruble, the free constant is significant and is equal to approximately 0.005 (reminder: the equation is evaluated in logarithms).

Including the 2008-2009 crisis period in the sample would be inappropriate, as covered interest parity did not hold at that time. However, losses incurred during currency crises may offset returns on foreign exchange carry trade strategies. Due to this offset uncovered interest parity may hold over longer time horizons.

Weighted least squares is used to account for increased variance in the errors after 2008 . 
Table 2

$\beta$ parameter for Russia.

\begin{tabular}{lcc}
\hline & Entire sample & Excluding the crisis period \\
\hline Simple least squares & 1.63 & $0.27^{a}$ \\
& $(0.63)^{b}$ & $(0.55)$ \\
Weighted least squares & 1.14 & 0.78 \\
& $(0.30)$ & $(0.20)$ \\
\hline
\end{tabular}

$a^{a}$ The parameter is insignificant.

${ }^{b}$ Standard deviations are listed in parentheses.

Source: Authors' calculations.

\subsection{Main results and their interpretation}

As is shown above, the forward premium puzzle was not observed in the RUBUSD pair between August 2001 and May 2014 except for the period running from October 2008 to February 2009, when the CIP was not realized. Therefore, the transition from targeting the USD to targeting the dual-currency basket did not entail a forward premium puzzle (UIP failure) as assumed in Sokolov et al. (2009). The rise in uncertainty with respect to the real exchange rate of the ruble after 2008 and 2009 did not lead to a forward premium puzzle either, as could be assumed from the hypothesis in Frankel and Poonawala (2010).

UIP holds when we include the constant term in equation (6). A significant constant means that the forward premium does not fully explain changes in the exchange rate. We can assume that this constant reflects the constant risk premium.

The interpretation of the significant constant in equation (6) corresponds to the result shown above: a constant risk premium explains carry trade returns. The existence of a significant constant helps link UIP with the result obtained in Menkhoff et al. (2012) using data for 2004-2010, when the ruble offers some of the highest returns in currency portfolios that utilized momentum strategies (a version of a speculative foreign exchange strategy). Momentum strategies in Russia brought earnings based on the risk premium, which is reflected in the constant in equation (6).

The period under consideration can be divided into two parts: before and after the 2008-2009 crisis. The first part is characterized by rapid economic growth, an inflow of capital, the accumulation of foreign debt in foreign currencies, a stable increase in the real exchange rate despite attempts to target the exchange rate, and an accumulation of international reserves. After the crisis, the economy witnessed considerably slower growth, increased and stabilized spread between rates on Russian and global inter-bank markets, the Bank of Russia transitioning towards inflation targeting, real rates on deposits exceeding zero more often (Fig. 3), and slightly slower reserve and debt increases.

The trend towards a continuous ruble appreciation and increased capital inflow (observed until the $3^{\text {rd }}$ quarter of 2008) stopped. The rate became more difficult to predict after 2008. Contrary to the hypothesis of Frankel and Poonawala (2010), which argues that in EMEs the forward premium puzzle holds due to the simplicity of predicting the exchange rate, data for the period following 2008 suggest absence of the forward premium puzzle in Russia at that time as well.

Hypothetical explanation of the facts implies that UIP held in Russia in the 2000s and thereafter, if the constant currency risk premium is taken into 


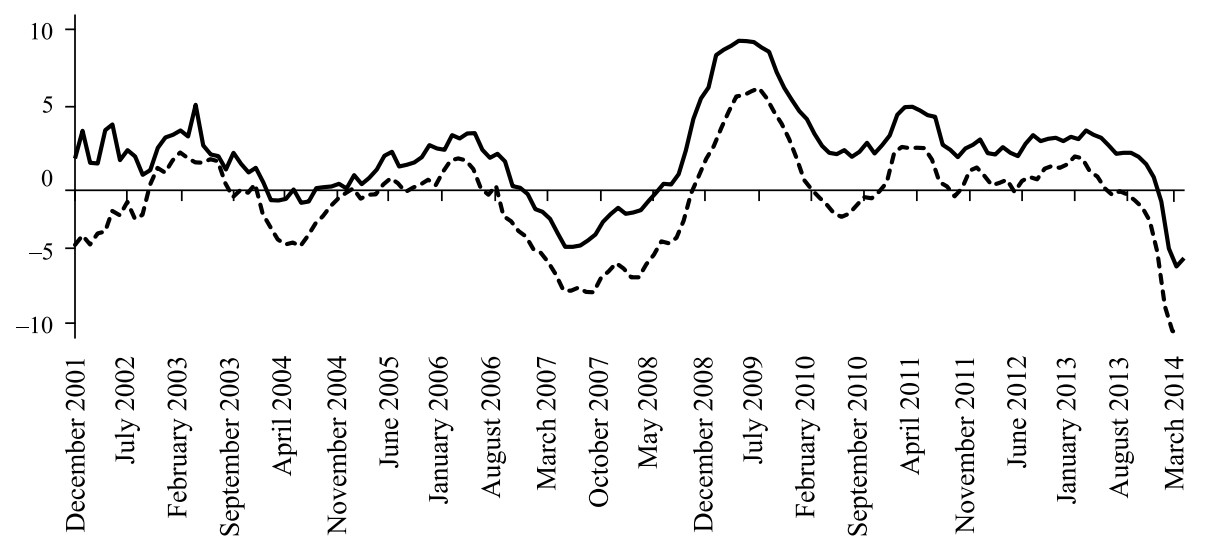

$$
\text { ---- On deposits — On loans }
$$

Fig. 3. Real interest rates in Russia.

Sources: Bank of Russia; Haver Analytics; authors' calculations.

account. The constant value of the risk premium is attributable to two factors: (1) the vast majority of foreign debt was denominated in foreign currencies; (2) the Bank of Russia accumulated reserves, providing "insurance" for banks and for major companies, which in turn accumulated foreign debt.

This hypothetical explanation is supported by the following empirical facts. Foreign exchange risk was borne by foreign debt borrowers, i.e., major national banks and companies. From 2004 to 2014, the share of foreign debt denominated in Russian rubles ranged between $15 \%$ and $25 \%$ (Fig. 4). At the same time, nearly all foreign debt was accumulated by banks and major companies.

The considerable reserves accumulated by the Bank of Russia insured banks and companies against foreign exchange risk. The Bank of Russia supported the banking sector during the foreign exchange crises of 2014 and 2015 and

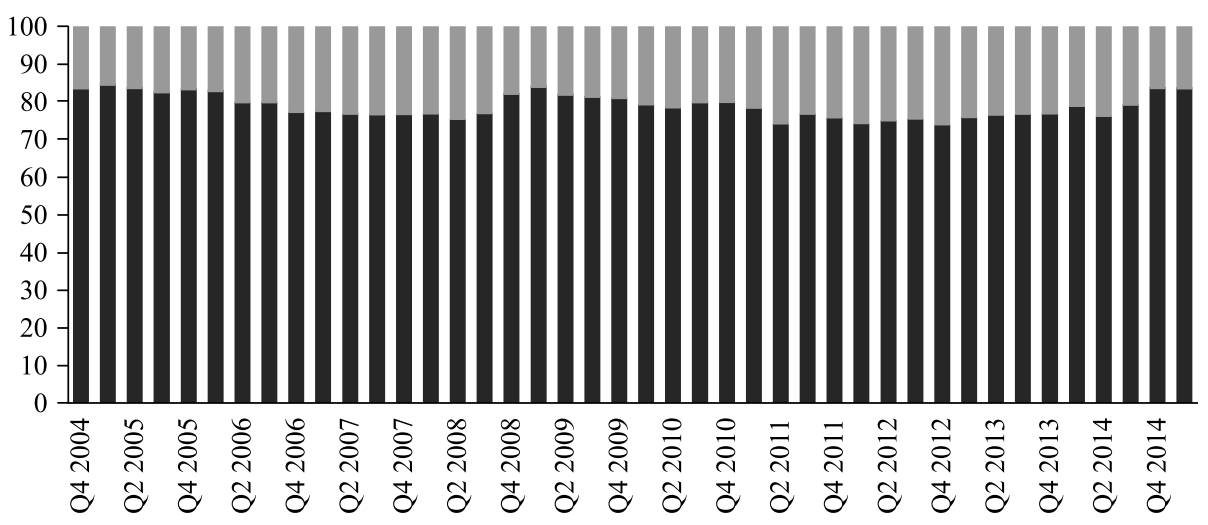

- Banks and other sectors: foreign currency Banks and other sectors: national currency

Fig. 4. Currency composition of foreign debt in Russia (\%).

Sources: Bank of Russia; Haver Analytics. 
primarily in 2008 and 2009. ${ }^{2}$ From August 2008 until mid-January 2009, during a gradual devaluation, the Bank of Russia spent USD 200 billion while increasing the provision of ruble liquidity, including unsecured liquidity. As a result of government support, foreign exchange risk was not realized in full, and the banking system managed to retain positive returns on assets and capital in 2008 and 2009.

EMEs tended to accumulate large international reserves while the private sector accumulated short-term foreign debt (Rodrik, 2006; Alfaro and Kanczuk, 2013). The share of Russia's short-term foreign debt (up to 1 year according to the Bank of Russia's methodology) has not exceeded 25\% since 2004. At the same time, events occurring in 2008 showed that the economy was susceptible to margin calls: the drop in collateral prices led to capital flight (IMF, 2012b).

The foreign debt functioned as a source of cheap investment financing for banks and major companies in Russia while the ruble was on the rise. International reserves acted as insurance. The growth of reserves was accompanied by an increase in the money supply and by high inflation, costs that the economy had to endure while accumulating foreign debt and international reserves.

In Russia's case, the accumulation of debt by the private sector and the simultaneous accumulation of reserves by the Central Bank resulted in low borrowing costs for banks. This was at least one of the factors that kept the real rate on deposits below zero (see Fig. 3).

\section{UIP in advanced and emerging market economies}

We can use data on AEs and EMEs to test the hypothesis formulated in the above section, according to which the risk premium is less volatile in economies where the foreign exchange risk of economic agents is insured by the central bank. Consequently, such economies have no forward premium puzzle.

First, we verify the existence of a forward premium puzzle for two groups of countries. The test results show that this phenomenon is almost non-existent in EMEs. Moreover, the significance of the free constant in equation (6) is evaluated for each country studied assuming that the absence of a forward premium puzzle coincides with the existence of a significant constant. The result obtained in Burnside (2015) was confirmed: in AEs, returns on carry trade financial portfolios are attributable to a volatile risk premium whereas in EMEs, returns on carry trade financial portfolios are attributable to a constant risk premium.

\subsection{The forward premium puzzle in $A E s^{3}$ and EMEs}

Equation (6) is estimated using unbalanced panel data gathered for 38 countries from the Bloomberg ${ }^{4}$ database. The number of countries in the sample was limited by the availability of data on forward foreign exchange rates. The observation begins in 1984.

\footnotetext{
2 This paper lists only some measures used by the Bank of Russia. A detailed description of anti-crisis measures used by the Russian government can be found in: IMF (2009, p. 10; 2012a).

${ }^{3}$ We included South Korea, which became an advanced economy relatively recently, the unique city state of Singapore, and the autonomous city of Hong Kong in the group of EMEs.

${ }^{4}$ We used the Bloomberg source for forward rates: RUB1M: BGN.
} 
We excluded observations related to periods in which the CIP did not hold from the series, following DellaCorte et al. (2015). We used monthly data and month-ahead forward rates.

The results of the panel analysis reveal differences between AEs and EMEs and are consistent with the results of Bansal and Dahlquist (2000) and Frankel and Poonawala (2010). The forward premium puzzle was not confirmed for the group of 28 currencies of EMEs and was confirmed for the group of 10 currencies of AEs (for calculations related to Eurozone countries, we used only one currency without taking into account earlier data, e.g., the French franc). Table 3 shows our main results.

According to Hassan and Mano (2014), estimates of the $\beta$ factor in a regression based on data without a panel structure (pooled regression) are biased downwards. In other words, the average value of the $\beta$ factor creates a distorted perception about interest parity across groups of countries. At the same time, this peculiarity does not disprove differences between AEs and EMEs in realizing UIP.

Tables 4 and 5 show the estimates of the weighted least squares test for each country and for the system of seemingly unrelated regressions (SUR). These estimates show that the $\beta$ factor in equation (6) is less than zero (i.e., there is a forward premium puzzle) for the majority of AEs and only for a few EMEs.

Table 3

Testing interest parity.

\begin{tabular}{lll}
\hline Country sample & $\beta$ & Standard deviation \\
\hline Advanced economies, 1984-2014 & 0.0423 & 0.234 \\
Emerging market economies, 1988-2014 & 0.6740 & 0.111 \\
Emerging market economies, 1988-2014 & 0.6910 & 0.116 \\
$\quad$ (excluding periods in which the CIP did not hold) & & \\
\hline
\end{tabular}

Note: Evaluation method-NE-RE (denotes no effect for the country and random effects occurring over the time period).

Source: Authors' calculations.

\section{Table 4}

Weighted least squares method-SUR.

\begin{tabular}{|c|c|c|c|c|c|}
\hline Country & Coefficient & Value & Std. error & $t$-statistic & Prob. \\
\hline \multirow[t]{2}{*}{ Bulgaria } & $\alpha$ & 4.568437 & 1.801029 & 2.536571 & 0.0112 \\
\hline & $\beta$ & -0.055452 & 1.036758 & -0.053486 & 0.9573 \\
\hline \multirow[t]{2}{*}{ Croatia } & $\alpha$ & 1.283306 & 0.941467 & 1.363091 & 0.1729 \\
\hline & $\beta$ & 0.951426 & 1.142279 & 0.832918 & 0.4049 \\
\hline \multirow[t]{2}{*}{ Lithuania } & $\alpha$ & 1.186923 & 0.672663 & 1.764513 & 0.0777 \\
\hline & $\beta$ & -0.256341 & 0.567452 & -0.451741 & 0.6515 \\
\hline \multirow[t]{2}{*}{ Estonia } & $\alpha$ & 2.702978 & 5.465775 & 0.494528 & 0.6209 \\
\hline & $\beta$ & -0.210972 & 0.628829 & -0.335500 & 0.7373 \\
\hline \multirow[t]{2}{*}{ Latvia } & $\alpha$ & 4.131763 & 2.552253 & 1.618869 & 0.1055 \\
\hline & $\beta$ & 0.225936 & 0.523374 & 0.431692 & 0.6660 \\
\hline \multirow[t]{2}{*}{ Romania } & $\alpha$ & -0.663996 & 1.121748 & -0.591930 & 0.5539 \\
\hline & $\beta$ & -0.590093 & 0.664642 & -0.887837 & 0.3747 \\
\hline \multirow[t]{2}{*}{ Russia } & $\alpha$ & 5.081643 & 1.327865 & 3.826927 & 0.0001 \\
\hline & $\beta$ & 0.835662 & 0.177682 & 4.703129 & 0 \\
\hline \multirow[t]{2}{*}{ Iceland } & $\alpha$ & -0.009626 & 0.010618 & -0.906556 & 0.3647 \\
\hline & $\beta$ & 2.832038 & 1.866348 & 1.517422 & 0.1292 \\
\hline \multirow[t]{2}{*}{ Czech Republic } & $\alpha$ & 1.589792 & 1.363253 & 1.166176 & 0.2436 \\
\hline & $\beta$ & -0.081047 & 1.227255 & -0.066039 & 0.9473 \\
\hline
\end{tabular}


Table 4 (continued)

\begin{tabular}{|c|c|c|c|c|c|}
\hline Country & Coefficient & Value & Std. error & $t$-statistic & Prob. \\
\hline \multirow[t]{2}{*}{ Hungary } & $\alpha$ & 0.002401 & 0.011156 & 0.215182 & 0.8296 \\
\hline & $\beta$ & -0.183360 & 2.726763 & -0.067244 & 0.9464 \\
\hline \multirow[t]{2}{*}{ Slovakia } & $\alpha$ & -0.006482 & 0.003651 & -1.775256 & 0.0759 \\
\hline & $\beta$ & -0.329470 & 1.488750 & -0.221306 & 0.8249 \\
\hline \multirow{2}{*}{ Slovenia } & $\alpha$ & -0.002295 & 0.004119 & -0.557175 & 0.5774 \\
\hline & $\beta$ & 0.117575 & 0.424865 & 0.276735 & 0.7820 \\
\hline \multirow[t]{2}{*}{ Hong Kong } & $\alpha$ & -1.257526 & 2.913392 & -0.431636 & 0.6660 \\
\hline & $\beta$ & -0.005152 & 0.051993 & -0.099087 & 0.9211 \\
\hline \multirow{2}{*}{ India } & $\alpha$ & 0.096366 & 0.408106 & 0.236130 & 0.8133 \\
\hline & $\beta$ & 0.211882 & 0.238097 & 0.889901 & 0.3735 \\
\hline \multirow[t]{2}{*}{ Indonesia } & $\alpha$ & -0.000816 & 0.002950 & -0.276688 & 0.7820 \\
\hline & $\beta$ & 0.684808 & 0.251666 & 2.721094 & 0.0065 \\
\hline \multirow[t]{2}{*}{ Malaysia } & $\alpha$ & -0.001070 & 0.001403 & -0.762537 & 0.4458 \\
\hline & $\beta$ & 0.605352 & 0.560023 & 1.080940 & 0.2798 \\
\hline \multirow[t]{2}{*}{ Philippines } & $\alpha$ & 0.000971 & 0.001474 & 0.658323 & 0.5104 \\
\hline & $\beta$ & 0.043128 & 0.148903 & 0.289637 & 0.7721 \\
\hline \multirow[t]{2}{*}{ Singapore } & $\alpha$ & 0.893998 & 0.486773 & 1.836580 & 0.0663 \\
\hline & $\beta$ & 0.019414 & 0.296496 & 0.065479 & 0.9478 \\
\hline \multirow[t]{2}{*}{ South Korea } & $\alpha$ & 0.424330 & 0.330471 & 1.284017 & 0.1992 \\
\hline & $\beta$ & 1.263445 & 0.708559 & 1.783120 & 0.0746 \\
\hline \multirow[t]{2}{*}{ Thailand } & $\alpha$ & -0.003266 & 0.002253 & -1.449782 & 0.1472 \\
\hline & $\beta$ & 1.253700 & 0.374704 & 3.345837 & 0.0008 \\
\hline \multirow[t]{2}{*}{ Saudi Arabia } & $\alpha$ & $-0.00108 \mathrm{E}^{-03}$ & $0.00128 \mathrm{E}^{-02}$ & -0.084909 & 0.9323 \\
\hline & $\beta$ & -0.011813 & 0.024083 & -0.490494 & 0.6238 \\
\hline \multirow[t]{2}{*}{ Kuwait } & $\alpha$ & -0.000847 & 0.000382 & -2.216960 & 0.0267 \\
\hline & $\beta$ & 0.654981 & 0.140163 & 4.672994 & 0 \\
\hline \multirow[t]{2}{*}{ Turkey } & $\alpha$ & 0.000986 & 0.003888 & 0.253542 & 0.7999 \\
\hline & $\beta$ & 0.483979 & 0.151652 & 3.191383 & 0.0014 \\
\hline \multirow[t]{2}{*}{ South Africa } & $\alpha$ & 0.960242 & 0.319086 & 3.009354 & 0.0026 \\
\hline & $\beta$ & -1.007552 & 0.667623 & -1.509164 & 0.1313 \\
\hline \multirow[t]{2}{*}{ Argentina } & $\alpha$ & -0.005704 & 0.002744 & -2.078706 & 0.0377 \\
\hline & $\beta$ & 0.745200 & 0.045838 & 16.257230 & 0 \\
\hline \multirow[t]{2}{*}{ Brazil } & $\alpha$ & -0.002782 & 0.006625 & -0.419939 & 0.6745 \\
\hline & $\beta$ & 0.609262 & 0.644054 & 0.945979 & 0.3442 \\
\hline Chile & $\alpha$ & -0.001337 & 0.002895 & -0.461709 & 0.6443 \\
\hline & $\beta$ & 1.201606 & 0.793133 & 1.515012 & 0.1298 \\
\hline Mexico & $\alpha$ & 0.003960 & 0.002592 & 1.527600 & 0.1267 \\
\hline & $\beta$ & -0.170692 & 0.302543 & -0.564191 & 0.5726 \\
\hline Australia & $\alpha$ & -0.000681 & 0.001410 & -0.483148 & 0.6290 \\
\hline & $\beta$ & -1.034062 & 0.709376 & -1.457706 & 0.1450 \\
\hline United Kingdom & $\alpha$ & -0.000105 & 0.002229 & -0.047293 & 0.9623 \\
\hline & $\beta$ & -0.077358 & 0.936913 & -0.082567 & 0.9342 \\
\hline Canada & $\alpha$ & 0.000119 & 0.001717 & 0.069526 & 0.9446 \\
\hline & $\beta$ & -0.444992 & 1.859915 & -0.239254 & 0.8109 \\
\hline Denmark & $\alpha$ & -0.000189 & 0.001147 & -0.165161 & 0.8688 \\
\hline & $\beta$ & 0.188248 & 0.688656 & 0.273356 & 0.7846 \\
\hline Japan & $\alpha$ & -0.000391 & 0.001444 & -0.271019 & 0.7864 \\
\hline & $\beta$ & -0.403266 & 0.274321 & -1.470050 & 0.1416 \\
\hline New Zealand & $\alpha$ & -0.002541 & 0.002255 & -1.126715 & 0.2599 \\
\hline & $\beta$ & -0.832035 & 0.740785 & -1.123181 & 0.2614 \\
\hline Norway & $\alpha$ & -0.002842 & 0.002763 & -1.028453 & 0.3038 \\
\hline & $\beta$ & 0.866343 & 0.940861 & 0.920798 & 0.3572 \\
\hline Sweden & $\alpha$ & 0.000103 & 0.001596 & 0.064670 & 0.9484 \\
\hline & $\beta$ & -0.041141 & 0.330024 & -0.124661 & 0.9008 \\
\hline Switzerland & $\alpha$ & $0.00624 \mathrm{E}^{-02}$ & 0.001690 & 0.036932 & 0.9705 \\
\hline & $\beta$ & 0.431064 & 0.374692 & 1.150450 & 0.2500 \\
\hline Eurozone & $\alpha$ & -0.002201 & 0.001684 & -1.306923 & 0.1913 \\
\hline & $\beta$ & -0.606863 & 0.490554 & -1.237097 & 0.2161 \\
\hline
\end{tabular}

Source: Authors' calculations. 
Table 5

Weighted least squares method.

\begin{tabular}{|c|c|c|c|c|c|}
\hline Country & Coefficient & Value & Std. error & $t$-statistic & Prob. \\
\hline \multirow[t]{2}{*}{ Bulgaria } & $\alpha$ & 3.813166 & 2.652927 & 1.437343 & 0.1507 \\
\hline & $\beta$ & 1.574322 & 1.823300 & 0.863446 & 0.3879 \\
\hline \multirow[t]{2}{*}{ Croatia } & $\alpha$ & 1.248966 & 0.959141 & 1.302172 & 0.1929 \\
\hline & $\beta$ & 0.746774 & 1.181040 & 0.632303 & 0.5272 \\
\hline \multirow{2}{*}{ Lithuania } & $\alpha$ & 1.905783 & 0.999387 & 1.906952 & 0.0566 \\
\hline & $\beta$ & 0.395206 & 1.182434 & 0.334231 & 0.7382 \\
\hline \multirow[t]{2}{*}{ Estonia } & $\alpha$ & 5.807222 & 7.646425 & 0.759469 & 0.4476 \\
\hline & $\beta$ & -1.094828 & 1.355177 & -0.807886 & 0.4192 \\
\hline \multirow[t]{2}{*}{ Latvia } & $\alpha$ & 4.198999 & 4.017425 & 1.045197 & 0.2960 \\
\hline & $\beta$ & -0.213387 & 0.992510 & -0.214997 & 0.8298 \\
\hline \multirow[t]{2}{*}{ Romania } & $\alpha$ & 0.494368 & 1.484805 & 0.332952 & 0.7392 \\
\hline & $\beta$ & -1.254164 & 0.931401 & -1.346535 & 0.1782 \\
\hline \multirow[t]{2}{*}{ Russia } & $\alpha$ & 5.835771 & 1.746018 & 3.342332 & 0.0008 \\
\hline & $\beta$ & 0.775033 & 0.257411 & 3.010873 & 0.0026 \\
\hline \multirow[t]{2}{*}{ Iceland } & $\alpha$ & -0.003290 & 0.012564 & -0.261884 & 0.7934 \\
\hline & $\beta$ & 1.331413 & 2.221223 & 0.599405 & 0.5489 \\
\hline \multirow[t]{2}{*}{ Czech Republic } & $\alpha$ & 2.130543 & 1.673547 & 1.273071 & 0.2030 \\
\hline & $\beta$ & -0.222313 & 1.752365 & -0.126865 & 0.8991 \\
\hline \multirow[t]{2}{*}{ Hungary } & $\alpha$ & 0.000115 & 0.015851 & 0.007249 & 0.9942 \\
\hline & $\beta$ & 0.580593 & 3.937464 & 0.147453 & 0.8828 \\
\hline \multirow[t]{2}{*}{ Slovakia } & $\alpha$ & -0.006036 & 0.004184 & -1.442821 & 0.1491 \\
\hline & $\beta$ & -0.830621 & 1.783924 & -0.465615 & 0.6415 \\
\hline \multirow[t]{2}{*}{ Slovenia } & $\alpha$ & -0.002293 & 0.004191 & -0.547038 & 0.5844 \\
\hline & $\beta$ & 0.107089 & 0.433660 & 0.246943 & 0.8050 \\
\hline \multirow[t]{2}{*}{ Hong Kong } & $\alpha$ & -0.696391 & 2.993489 & -0.232635 & 0.8161 \\
\hline & $\beta$ & -0.000225 & 0.055528 & -0.004055 & 0.9968 \\
\hline \multirow[t]{2}{*}{ India } & $\alpha$ & -0.035051 & 0.491013 & -0.071385 & 0.9431 \\
\hline & $\beta$ & 0.215610 & 0.301915 & 0.714142 & 0.4752 \\
\hline \multirow[t]{2}{*}{ Indonesia } & $\alpha$ & -0.001572 & 0.003563 & -0.441252 & 0.6590 \\
\hline & $\beta$ & 0.637640 & 0.334950 & 1.903688 & 0.0570 \\
\hline \multirow[t]{2}{*}{ Malaysia } & $\alpha$ & -0.001815 & 0.001767 & -1.026686 & 0.3046 \\
\hline & $\beta$ & 0.730364 & 0.825104 & 0.885178 & 0.3761 \\
\hline \multirow[t]{2}{*}{ Philippines } & $\alpha$ & 0.000597 & 0.00165 & 0.361462 & 0.7178 \\
\hline & $\beta$ & 0.003613 & 0.180613 & 0.020003 & 0.9840 \\
\hline \multirow[t]{2}{*}{ Singapore } & $\alpha$ & 0.933871 & 0.601557 & 1.552423 & 0.1206 \\
\hline & $\beta$ & -0.159353 & 0.486007 & -0.327883 & 0.7430 \\
\hline South Korea & $\alpha$ & 0.535145 & 0.393522 & 1.359887 & 0.1739 \\
\hline & $\beta$ & 0.989627 & 0.926736 & 1.067863 & 0.2856 \\
\hline Thailand & $\alpha$ & -0.003235 & 0.002567 & -1.260028 & 0.2077 \\
\hline & $\beta$ & 1.653831 & 0.479400 & 3.449796 & 0.0006 \\
\hline Saudi Arabia & $\alpha$ & $0.00120 \mathrm{E}^{-03}$ & $0.00129 \mathrm{E}^{-02}$ & 0.092904 & 0.9260 \\
\hline & $\beta$ & -0.012610 & 0.025109 & -0.502227 & 0.6155 \\
\hline Kuwait & $\alpha$ & -0.000957 & 0.000444 & -2.153195 & 0.0313 \\
\hline & $\beta$ & 0.755226 & 0.184788 & 4.086982 & 0 \\
\hline Turkey & $\alpha$ & -0.001993 & 0.004706 & -0.423404 & 0.6720 \\
\hline & $\beta$ & 0.563198 & 0.195935 & 2.874411 & 0.0041 \\
\hline South Africa & $\alpha$ & 0.702282 & 0.385105 & 1.823611 & 0.0682 \\
\hline & $\beta$ & -0.312795 & 0.821590 & -0.380719 & 0.7034 \\
\hline Argentina & $\alpha$ & -0.005883 & 0.002800 & -2.101192 & 0.0357 \\
\hline & $\beta$ & 0.757570 & 0.047657 & 15.896430 & 0 \\
\hline Brazil & $\alpha$ & -0.003562 & 0.007883 & -0.451797 & 0.6514 \\
\hline & $\beta$ & 0.410783 & 0.786995 & 0.521964 & 0.6017 \\
\hline Chile & $\alpha$ & -0.000774 & 0.002960 & -0.261614 & 0.7936 \\
\hline & $\beta$ & 0.810317 & 0.835941 & 0.969346 & 0.3324 \\
\hline Mexico & $\alpha$ & 0.002533 & 0.003117 & 0.812459 & 0.4166 \\
\hline & $\beta$ & -0.034061 & 0.392569 & -0.086766 & 0.9309 \\
\hline
\end{tabular}


Table 5 (continued)

\begin{tabular}{|c|c|c|c|c|c|}
\hline Country & Coefficient & Value & Std. error & $t$-statistic & Prob. \\
\hline \multirow[t]{2}{*}{ Australia } & $\alpha$ & -0.001814 & 0.002236 & -0.811182 & 0.4173 \\
\hline & $\beta$ & -3.558151 & 1.953197 & -1.821706 & 0.0685 \\
\hline \multirow[t]{2}{*}{ United Kingdom } & $\alpha$ & 0.000120 & 0.002710 & 0.044186 & 0.9648 \\
\hline & $\beta$ & 0.250764 & 1.246678 & 0.201146 & 0.8406 \\
\hline \multirow[t]{2}{*}{ Canada } & $\alpha$ & 0.000626 & 0.002057 & 0.304072 & 0.7611 \\
\hline & $\beta$ & 0.841703 & 2.647493 & 0.317925 & 0.7506 \\
\hline \multirow[t]{2}{*}{ Denmark } & $\alpha$ & -0.000128 & 0.001314 & -0.097789 & 0.9221 \\
\hline & $\beta$ & -0.441529 & 0.895777 & -0.492901 & 0.6221 \\
\hline \multirow[t]{2}{*}{ Japan } & $\alpha$ & -0.000408 & 0.001772 & -0.230351 & 0.8178 \\
\hline & $\beta$ & -0.640577 & 0.646343 & -0.991079 & 0.3217 \\
\hline \multirow[t]{2}{*}{ New Zealand } & $\alpha$ & -0.003452 & 0.002495 & -1.383369 & 0.1666 \\
\hline & $\beta$ & -1.330226 & 0.870804 & -1.527584 & 0.1267 \\
\hline \multirow[t]{2}{*}{ Norway } & $\alpha$ & -0.001423 & 0.003898 & -0.364972 & 0.7151 \\
\hline & $\beta$ & 0.138187 & 1.430159 & 0.096623 & 0.9230 \\
\hline \multirow[t]{2}{*}{ Sweden } & $\alpha$ & -0.000952 & 0.002006 & -0.474682 & 0.6350 \\
\hline & $\beta$ & 0.527003 & 0.646322 & 0.815388 & 0.4149 \\
\hline \multirow[t]{2}{*}{ Switzerland } & $\alpha$ & -0.000148 & 0.002078 & -0.071446 & 0.9430 \\
\hline & $\beta$ & 0.398224 & 0.714404 & 0.557421 & 0.5773 \\
\hline \multirow[t]{2}{*}{ Eurozone } & $\alpha$ & -0.003312 & 0.002112 & -1.568682 & 0.1168 \\
\hline & $\beta$ & -1.483096 & 0.964059 & -1.538388 & 0.1240 \\
\hline
\end{tabular}

Source: Authors' calculations.

\subsection{Carry trade in EMEs and AEs}

For each of the 38 countries reviewed, we compared returns on both the dynamic and static carry $\operatorname{trade}^{5}$ (Fig. 5.).

If the point in the chart is lower than the bisector, then the returns on dynamic carry trade exceed returns on static carry trade for the given currency. As we can see, the majority ( 8 out of 10) of AEs' currencies provided higher returns on dynamic carry trade. Only 10 of 28 currencies of EMEs provided higher returns on dynamic carry trade. ${ }^{6}$ This confirms the result obtained by Burnside (2015): in AEs, returns on carry trade financial portfolios are attributable to a volatile risk premium; in EMEs, returns on carry trade financial portfolios are attributable to a constant risk premium. It should be stressed that the calculated returns on carry trade in EMEs do not take into account periods in which covered interest parity did not hold. In addition, the length of the series for each country varied and was subject to data availability.

\subsection{Summing up and testing the hypothesis}

Table 6 compares AEs and EMEs meeting one of the two following criteria: (1) an estimation of equation (6) yields a significant and positive $\beta$ factor; (2) the risk premium is not constant. This comparison does not confirm the initial hypothesis. First, a constant risk premium (obtained by evaluating the risk premium trend for carry trade) does not guarantee significance for the constant in equation (6) - see, e.g., results for South Korea and Turkey. Second, high

\footnotetext{
${ }^{5}$ For an explanation of the calculations, see Section 2.2 above, equations (4) and (5).

${ }^{6}$ Hong Kong and Singapore have higher returns on dynamic carry trade.
} 


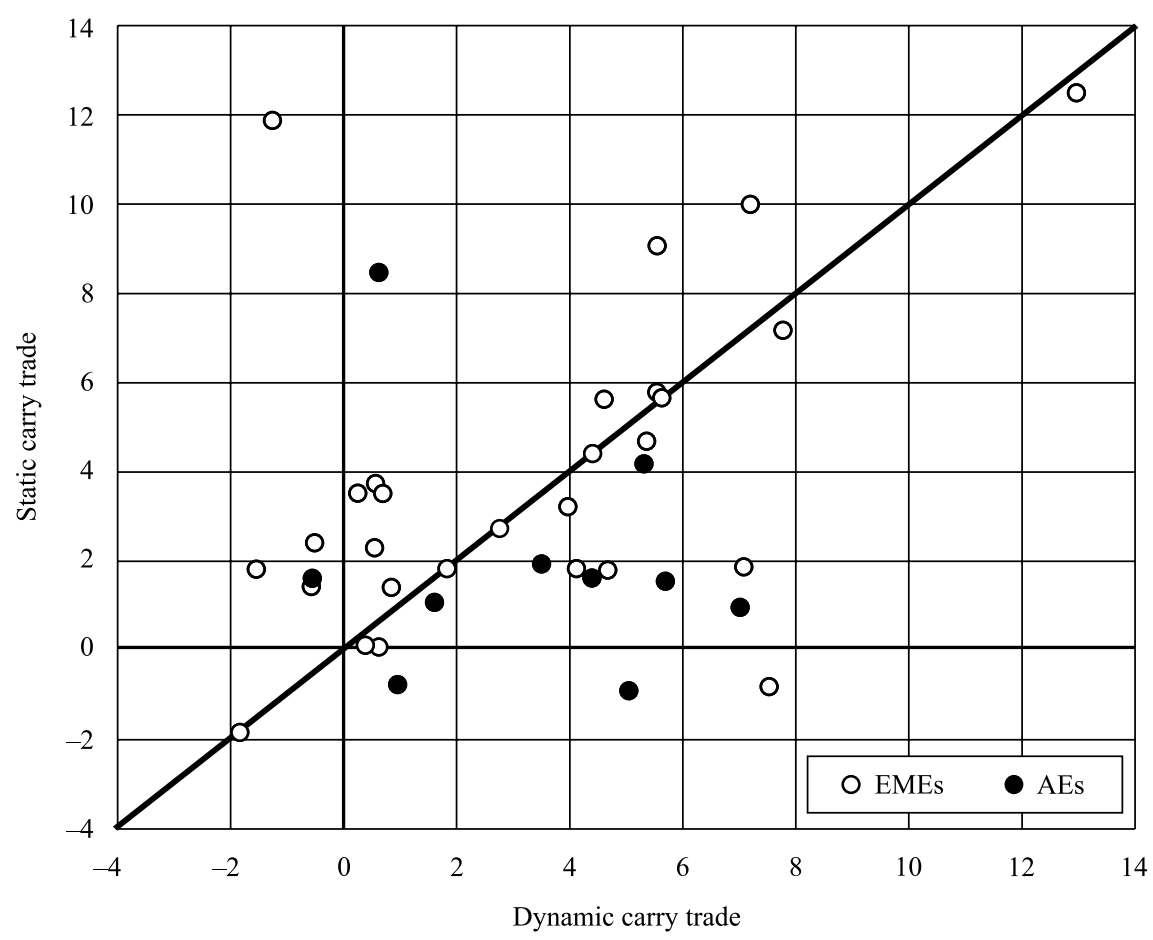

Fig. 5. Returns on carry trade strategies for particular currencies.

Source: Authors' calculations.

Table 6

Comparisons of equation (6) evaluations and the behavior of risk premiums for certain countries.

\begin{tabular}{|c|c|c|c|}
\hline & $\beta>0$ and is significant & $\alpha$ is significant & Risk premium is constant \\
\hline Russia & + & + & + \\
\hline South Korea & + & - & + \\
\hline Kuwait & + & + & + \\
\hline Turkey & + & - & + \\
\hline Argentina & + & + & - \\
\hline Indonesia & + & - & - \\
\hline Thailand & + & - & - \\
\hline Hungary & - & - & - \\
\hline Saudi Arabia & - & - & - \\
\hline India & - & - & - \\
\hline Czech Republic & - & - & - \\
\hline Romania & - & - & - \\
\hline Estonia & - & - & - \\
\hline Hong Kong & - & - & - \\
\hline Singapore & - & - & - \\
\hline Australia & - & - & - \\
\hline United Kingdom & - & - & - \\
\hline Canada & - & - & - \\
\hline Denmark & - & - & - \\
\hline Japan & - & - & - \\
\hline New Zealand & - & - & - \\
\hline Norway & - & - & - \\
\hline Sweden & - & - & - \\
\hline Switzerland & - & - & - \\
\hline Eurozone & - & - & - \\
\hline
\end{tabular}

Source: Authors' calculations. 
reserves (Indonesia, India, and Thailand ${ }^{7}$ ) do not guarantee a stable risk premium. As a stipulation, since 2009, these three countries have demonstrated an increase in foreign debt denominated in the national currency. It is probable that testing the hypothesis based on data for South Korea, Turkey, Indonesia, India, and Thailand was complicated by the existence of certain additional facts, causing the hypothesis to not be confirmed for these data.

\section{Conclusion}

This study shows that the data for Russia do not confirm the existence of a forward premium puzzle. If the uncovered parity equation accounts for the constant risk premium in the form of a constant term, based on monthly data for 2001 to 2014, we can state that uncovered interest parity holds in Russia. The existence of a significant constant term is consistent with the fact that carry trade returns in Russia are driven by a constant risk premium.

By comparing these empirical facts with specific features of the Russian economy, we find a hypothetical explanation for why UIP holds in Russia and not in most other countries. We can assume that high reserves of the Central Bank acted as insurance against foreign exchange risk for economic agents accumulating foreign debt in foreign currencies. This hypothesis can also explain differences in returns on carry trade portfolios found in Burnside (2015).

Although this hypothesis appears to be credible, it cannot be proven based on data for EMEs and AEs at this point in time. This may be related to our insufficient understanding of the specifics of other economies and consequently to our failure to take them into account in verifying UIP. At the same time, testing UIP based on data for EMEs and AEs confirms earlier results: the forward premium puzzle does not exist for the group of EMEs studied (Bansal and Dahlquist, 2000; Frankel and Poonawala, 2010). Returns on carry trade in EMEs are attributable to the static risk premium, unlike returns on carry trade in AEs (Burnside, 2015).

\section{References}

Adolfson, M., Laseen, S., Linde, J., \& Villani, M. (2007). Bayesian estimation of an open economy DSGE model with incomplete pass-through. Journal of International Economics, 72 (2), 481-511.

Alfaro, L., \& Kanczuk, F. (2013). Debt redemption and reserve accumulation. Harvard Business School Working Paper, No. 13-074.

Baba, N., \& Packer, F. (2009). Interpreting deviations from covered interest parity during the financial market turmoil of 2007-2008. Journal of Banking \& Finance, 33 (11), 1953-1962.

Backus, D. K., Foresi, S., \& Telmer, C. I. (2001). Affine term structure models and the forward premium anomaly. Journal of Finance, 56 (1), 279-304.

Bansal, R., \& Dahlquist, M. (2000). The forward premium puzzle: Different tales from developed and emerging economies. Journal of International Economics, 51 (1) 115-144.

Bilson, J. F. O. (1981). The "speculative efficiency" hypothesis. Journal of Business, 54 (3), 435-451.

Brandt, M. W., Cochrane, J. H., \& Santa-Clara, P. (2006). International risk sharing is better than you think, or exchange rates are too smooth. Journal of Monetary Economics, 53 (4), 671-698.

Burnside, C. (2012). Carry trades and risk. In J. James, I. W. Marsh, \& L. Sarno (Eds.), Handbook of exchange rates (pp. 283-312). Hoboken, NJ: Wiley.

\footnotetext{
${ }^{7}$ Reserve sufficiency metric values are 143\% for Indonesia, 155\% for India, and 187\% for Thailand while the norm ranges between $100 \%$ and $150 \%$ (IMF, 2015).
} 
Burnside, C. (2015). The carry trade in industrialized and emerging markets. In C. Raddatz, D. Saravia, \& J. Ventura (Eds.), Global liquidity, spillovers to emerging markets and policy responses (pp. 245-280). Santiago, Chile: Central Bank of Chile.

Burnside, C., Eichenbaum, M., \& Rebelo, S. (2012). Understanding the profitability of currencytrading strategies. NBER Reporter, No. 3: Research summary.

Chinn, M., \& Meredith, G. (2004). Monetary policy and long-horizon uncovered interest parity. IMF Staff Papers, 51 (3), 409-430.

Chinn, M. D. (2006). The (partial) rehabilitation of interest rate parity in the floating rate era: Longer horizons, alternative expectations, and emerging markets. Journal of International Money and Finance, 25 (1), 7-21.

Chinn, M. D., \& Quayyum, S. (2012). Long horizon uncovered interest parity re-assessed. NBER Working Paper, No. 18482.

Clarida, R., Davis, J., \& Pedersen, N. (2009). Currency carry trade regimes: Beyond the Fama regression. Journal of International Money and Finance, 28 (8), 1375-1389.

Della Corte, P., Riddiough, S., \& Sarno, L. (2015). Currency premia and global imbalances. Review of Financial Studies, 29 (8), 2161-2193

Engel, C. (2015). Exchange rates and interest parity. In G. Gopinath, E. Helpman, \& K. Rogoff (Eds.), Handbook of international economics (Vol. 4, pp. 453-522). San Diego and Amsterdam: Elsevier.

Evans, M. (2011). Exchange-rate dynamics. Princeton: Princeton University Press.

Frankel, J., \& Poonawala, J. (2010). The forward market in emerging currencies: Less biased than in major currencies. Journal of International Money and Finance, 29 (3), 585-598.

Galati, G., Heath, A., Mcguire P. (2007). Evidence of carry trade activity. BIS Qaurterly Review, $3,27-41$.

Gurvich, E. T., Sokolov, V. N., \& Ulyukaev, A. V. (2009). The impact of the exchange rate policy on the interest rates: Uncovered and covered interest rate parity. Zhurnal Novoy Ekonomicheskoy Assotsiatsii, 1-2, 104-126 (In Russian).

Hansen, L. P., \& Hodrick, R. J. (1980). Forward exchange rates as optimal predictors of future spot rates: An econometric analysis. Journal of Political Economy, 88 (5), 829-853.

Hassan, T., \& Mano, R. (2014). Forward and spot exchange rates in a multi-currency world. NBER Working Paper, No. 20294.

IMF (2009). Russian Federation: 2009 Article IV consultation: Staff report (IMF Country Report No. 09/246). Washington, DC: International Monetary Fund.

IMF (2012a). Russian Federation: Staff report for the 2015 Article IV consultation (IMF Country Report No. 15/211). Washington, DC: International Monetary Fund.

IMF (2012b). Russian Federation: Selected issues: Banking sector and financial market conditions (IMF Country Report No. 12/218). Washington, DC: International Monetary Fund.

IMF (2015). 2015 external sector report. Washington, DC: International Monetary Fund.

Kollmann, R. (2004). Welfare effects of a monetary union. Journal of the European Economic Association, 2 (2-3), 289-301.

Lewis, K. K. (1995). Puzzles in international financial markets. In G. M. Grossman, \& K. Rogoff (Eds.), Handbook of international economics (Vol. 3, pp. 1913-1971). San Diego and Amsterdam: Elsevier.

Menkhoff, L., Sarno, L., Schmeling, M., \& Schrimpf, A. (2012). Carry trades and global foreign exchange volatility. Journal of Finance, 67 (2), 681-718.

Rodrik, D. (2006). The social cost of foreign exchange reserves. International Economic Journal, $20(3), 253-266$.

Wang, J. (2010). Home bias, exchange rate disconnect, and optimal exchange rate policy. Journal of International Money and Finance, 29 (1), 55-78. 